\title{
Editorial Paper: Exploring Management Through Qualitative Research - Introductory Remarks
}

Marta Najda-Janoszka ${ }^{1}$, Corina Daba-Buzoianu ${ }^{2}$

\section{INTRODUCTION}

Our intention with this special issue is to continue a rich, scholarly dialogue on producing insightful qualitative research in the management field. Being engaged in fieldwork through varied research endeavors, we have experienced challenges and uncertainties when doing qualitative research (e.g., NajdaJanoszka, 2016a, 2016b; Daba-Buzoianu, Bira, Tudorie \& Duduciuc, 2017; Daba-Buzoianu \& Bira, 2017). Despite a growing number of studies pertaining to the interpretative approach, there are no universal standards for conducting qualitative inquiry (Bluhm, Harman, Lee, \& Mitchell, 2010; Cassell \& Symon, 2015). Moreover, advocates of qualitative research have been arguing against development of such standards (Sinkovics \& Alfoldi, 2012; Pratt, 2009), because it could put at risk the fluid and emergent nature of qualitative research (Cassell \& Symon, 2015). Hence, the enduring dilemma relates to the balance between the creative, inherent messiness of qualitative research and methodological rigor (Cyfert, 2014; Sinkovics \& Alfoldi, 2012). We agree with the standpoint of Symon,- Cassell and Johnson (2016) that evaluation criteria should not marginalize alternative perspectives nor impose unified normative practices. Representing different research backgrounds (strategic management, communication) as well as perspectives (organizational, individual) we have discussed promising opportunities for management studies stemming from confronting distinct research traditions within an

1 Marta Najda-Janoszka, Ph.D., Associate Professor, Jagiellonian University, Faculty of Management and Social Communication, Ul. Łojasiewicza 4, 30-348 Krakow, Poland, e-mail: eknajda@cyfronet.pl

2 Corina Daba-Buzoianu, Ph.D., Assistant Professor, National University of Political Studies and Public Administration, Bd. Expoziției 30A, sector 1, etaj 2-4, București 010324, Bucharest, Romania, e-mail: corina.buzoianu@comunicare.ro 
interpretive approach. The biennial conference, Qualitative Research in Communication (QRC) in Bucharest, provided the perfect environment to enhance such a debate and resulted in a call for this special issue. Papers included in the issue do not contribute to the standardization trend but are expected to show the diversity of methods used and phenomena studied in the qualitative research in management.

\section{Observed progress}

There is no doubt that qualitative research is very much linked to the significant changes that dominated the $20^{\text {th }}$ century and that emphasized the importance of exploring rather than inquiring (Denzin \& Lincoln, 1994; Guba \& Lincoln, 2005; Lindlof \& Taylor, 2011). Through qualitative research, individuals and processes are considered in their inner diversity as the researcher does not aim to find specific answers but instead looks for new questions and answers to understand the meanings that individuals give to their life (Paille, 2002; Daba-Buzoianu \& Bira, 2017). Most important is the fact that the development of qualitative methodologies is linked to the supremacy of Western epistemologies and to the attempt to understand new contexts, phenomenon and behaviors that were impossible to study by quantitative means. Qualitative research has a comprehensive character and has been opposed to positivism and post-positivism, trying to depict the reality through a phenomenological approach (Guba \& Lincoln, 2005; Willig, 2008; Lindlof \& Taylor, 2011).

For many years, qualitative research has been referred to as opposed to the scientific and rigorous quantitative studies and has been considered subjective and a way of producing soft science (Lindlof \& Taylor, 2011; Taylor \& Lindlof, 2013). Although qualitative research tends to be the dominant methodology in some fields (e.g., communication, see Lindlof \& Taylor, 2011), scholars still question qualitative studies and ask for more standardized research tools and techniques. Of all the critiques, generalizability is probably the most widespread issue that qualitative research has to deal with (Silverman, 2006). Although scholars consider that generalizability should not be considered a goal anymore, this dispute is still visible. This is why researchers try to turn the debate towards explanations of meanings, which can be regarded as transferable to another setting (Mason, 2017). Analyzing qualitative results in connection with quantitative surveys and using theoretical samplings (Paille, 2002) are some of the options available for researchers interested in doing qualitative research and aiming to reach validity.

The continuous growth of interest in qualitative research in management studies that has been observed over the past decades (Lee, Mitchell, \& 
Sablynski, 1999; Bluhm, Harman, Lee, \& Mitchell, 2010) confirms the increased recognition of the strengths of qualitative inquiry with regard to issues of context and timing in organizational affairs (Langley, Smallman, Tsoukas, \& Van de Ven, 2013). According to published literature reviews, qualitative research within the discipline of management has repositioned itself from a marginalized avant-garde into the mainstream (Bluhm et al., 2010; Symon, Cassell, \& Johnson, 2016). A growing number of management scholars reach for qualitative methods, as they are better suited to enhancing the understanding of the meaning of actions in real-life contexts (Denzin \& Lincoln, 2000) and the temporal flow of organizational life (Langley et al., 2013). Qualitative research tools are invaluable for opening the "black box" of abstractly defined contextual variables (e.g., power position) and addressing uncharted knowledge territories of the managerial landscape (Eisenhardt, 1989; Eisenhardt \& Graebner, 2007; Edmondson \& McManus, 2007). It has been argued that qualitative research is particularly helpful in addressing grand challenges, i.e., "complex problems with significant implications, unknown solutions, and intertwined and evolving technical and social interactions" (Eisenhardt, Graebner, \& Sonenshein, 2016, p. 1115). Allowing for a deep dive into varied types of rich data (text, pictures, videos, social media posts) qualitative research facilitates novel insights and enables contextual understanding of abstract, hard-to-measure constructs, and unusual and emerging phenomena (Eisenhardt,Graebner, \& Sonenshein, 2016). Not without reason, papers using inductive methods are among the most highly cited at the most prestigious management journals (e.g., AMJ, AM, SMJ), as well as having become recognized as the most interesting ones (Bartunek, Rynes, \& Ireland, 2006; Eisenhardt et al., 2016).

As pointed out by Kociatkiewicz and Kostera (2014), the contribution of psychology and sociology has been present from the very emergence of management studies, thus reaching for methods used in those disciplines appears to be a natural and logical consequence when understanding management studies in terms of "an engagement undertaken with the aim of increasing the wellbeing of organizational participants" (p. 9). Hence, the extent management scholarship presents seminal examples of innovative approaches that broaden the exploratory scope, e.g. application of discourse analysis (Jørgensen, Jordan, \& Mitterhofer, 2012), narrative approach (Vaara, Sonenshein, \& Boje, 2016), visual methods (Davidson et al., 2012), ethnographic observation (Seidel \& O'Mahoney, 2014). The potential for understanding the complexities of management expands with the strong wave of methodological innovation. 


\section{Challenges ahead}

Nevertheless, despite the advances in qualitative research in management studies, there are still important challenges to overcome when it comes to conducting qualitative inquiry and publicizing the obtained results (see editorials for AMJ, SMJ; Pratt, 2009). The very nature of the qualitative research, which requires immersion in data and a multi-perspective reflection on gathered material, makes those tasks highly difficult. There are no algorithms for producing the fieldwork in qualitative research, as the research is often designed at the same time that it is being done (van Maanen, 1998) since "qualitative methods need to be elaborated or modified for each new application" (Gephart, 2004, p. 458). On the one hand, such a fluid nature enhances fresh and unexpected insights that contribute to, or even open, new research avenues. On the other hand, a non-linear research process involving various shifts during the study makes it harder for researchers to manage such "messiness," as well as to succinctly explain research evolvement within the limited space of an article. Scholars highlight the continuous need for works providing practices that contribute to the strengthening of the methodological fit of qualitative research in management and organization studies (Golden-Biddle \& Locke, 2007; Corley \& Gioia, 2011; Gioia, Corley, \& Hamilton, 2013). There is a consensus that a good paper, regardless of the qualitative or quantitative design, should present a clear contribution to theory, be well written and use transparently articulate methods (Pratt, 2009). However, these are very general criteria, leaving considerable room for maneuver for authors and reviewers. According to some researchers, developing more detailed guidelines that ensure theoretical and methodological consistency is of particular importance in the face of a growing trend towards plurality in perspectives, multi-paradigm approaches and mixed methods usage observed in management studies (Molina-Azorin, 2011; Molina-Azorin \& Cameron, 2015; Bazeley, 2010; Bluhm et al., 2010). It has been argued that the development of certain standards would help both reviewers in their evaluation and authors in improving the trustworthiness of the presented research. However, the observed tendency to enforce templates for qualitative research, and practices of mimicking the style of quantitative papers, has led many scholars to question such disciplinary, normative direction (Cassell, 2016; Symon et al., 2016; Sinkovics \& Alfoldi, 2012). They suggest that such guidelines, instead of helping qualitative writers, raise the risk of compromising detailed, explanatory theorizing - the heart of qualitative research - for linear, cause-effect theorizing typical of a quantitative approach (Cassell, 2016; Sinkovics \& Alfoldi, 2012). Moreover, pressure towards standardized compartmentalization of 
the content seems to ignore the fact that the balance between "showing and telling" (Pratt, 2009) is dynamic and is dependent on the topic studied, methods used, and richness of data gathered (Symon et al., 2016). Hence, scholars call for resistance to observed attempts to homogenize qualitative management research (Cassell, 2016). They emphasize that preserving the "messy," non-linear nature of the qualitative approach does not imply an "anything-goes stance" (Czakon, 2009; Gummesson, 2005; Denis, Lamothe, \& Langley, 2001). Although the qualitative research usually does not proceed unidirectionally through predefined stages, it is about performing research activities in a manner that ensures congruence between a chosen method, data analysis and a report of the findings (Eisenhardt \& Graebner, 2007; Sinkovics \& Alfoldi, 2012). Methodological rigor of the qualitative approach embraces reshaping the research during progress (Gummesson, 2005; Symon et al., 2016), yet requires transparency in reporting all turns and refinements (Eisenhardt \& Graebner, 2007). Given the amount and diversity of gathered data, an appropriate systematization, documentation and visualization of the whole research process can be quite challenging. Hence, a growing number of researchers report usage of Computer-Assisted Qualitative Data Analysis Software (CAQDAS). By enabling multimodal interaction with the data, CAQDAS can analyze large volumes of diverse data more manageable and transparent (Sinkovics \& Alfoldi, 2012; Maher, Hadfield, Hutchings, \& de Eyto, 2018). However, using software to analyze data raises certain concerns related to fragmentation and over-simplification of the analysis (Maher et al., 2018). The functionality of CAQDAS has proved to be invaluable when it comes to organizing gathered data and communicating the rigor of the research process (audit trail), yet it has been observed that digital tools unevenly support different types of cognition (Maher et al., 2018), which may affect further interpretation and reflection. Thus, caution with the application of software relates not so much to balancing as to a practical awareness that the analytical process remains the task of the researcher.

\section{Contributions to the special issue}

With growing recognition of its relevance, qualitative research has moved away from the periphery of the management field. However, heading towards the mainstream engenders concerns over the preservation of methodological openness and flexibility (e.g., Symon et al., 2016). The papers selected for this special issue address the problem by providing insights into the use of various qualitative methods across different contexts. By highlighting some current trends in the field and following a reflexive stance, the articles aim to 
enrich and inspire new debates regarding the realization of the potential of qualitative research in management studies.

The first paper, authored by Marta Gancarczyk and Joanna Bohatkiewicz (2018), discusses the concept of upgrading within cluster dynamics research. Although the extant literature provides quite a rich content on the dynamics of industrial agglomerations, the problem of cluster upgrading, understood as the advancement of the relative competitive position of clusters' dominant industries in global value chains (GVCs), is considered a new phenomenon in the field. Prospective approach and structural change orientation make the concept highly relevant for the adaptive and proactive planning of regional development. With the intent to identify and systemize the research streams in regional cluster upgrading, by capturing a broad horizon of theoretical lenses, the authors conducted an extensive narrative literature review. The qualitative approach that is introduced facilitates a comprehensive critical analysis of the extant literature and, as a result, enables the development of a cohesive map of research streams and interrelations between them (GVC governance, the resource-based view, evolutionary and life cycle concepts, lead-firm strategies, policy interventions) and an integrative framework for studying the antecedents of cluster upgrading. The formulated proposition of an integrative approach may serve to engender new debates on positive and normative objectives in regional development.

The second article, by Carmen Novac and Raluca Ciochină (2018), shifts the scope toward changes in the managerial philosophy which have been induced by developments in information technology. The authors have focused on the agile project management framework and, accordingly, on Scrum methodology. Although the agile approach has been implemented on a growing scale, in particular in the software industry, the extant literature provides a rather fragmentary picture of the actual performance of teams that undergo reorientation towards agile principles. Hence, in addressing the gap, the article presents a case study of an in-progress implementation of Scrum methodology by software development teams situated in Bucharest and Brussels. Using participant observation as the primary tool for collecting data enabled a deep immersion in a setting, which in turn facilitated a thorough exploration of inter-group relations and disclosure of "backstage realities." The authors have evaluated observed agile and coordination practices according to three criteria referring to value, stability and speed. The results that are presented shed more light on the process of redefining responsibilities, and the way it engenders the transformative flow in the distributed context. The insights and reflections provided by the research contribute to the discussion on the implementation challenges of agile methodologies, in particular by 
highlighting the contextual factors influencing the discrepancies that were observed between formal agile principles and actual practice.

Monica Bira's paper (2018) discusses management tools from a communication perspective, aiming to explore how museums can strengthen their relationship with key audiences. In doing so, Monica Bira puts under scrutiny online communication management in order to see possible usages in establishing stable relationship with stakeholders and in reinforcing a museum's mission and identity. The qualitative study of online communication management is done by considering content management and interaction management. As Bira's study reveals, by managing the content of communication and online interaction, museums find themselves in the situation of reassessing their identity. Moreover, the paper concludes that online communication management helps museums to act as a place of power, as they are pictured as a source of wisdom and knowledge.

Bianca-Florentina Cheregi (2018) proposes a multimodal analysis of the Republic of Moldova and Romania's tourism campaigns in the context of nation branding. The comparative semiotic analysis is a cross-cultural comparison of nation branding in the case of two countries sharing traditions and language. Cheregi looks at the logos, websites and videos from the two cases through a neoliberal perspective, paying attention to the marketization of public discourse. Nation branding can be seen as an instrument used in the construction of the other. The paper connects national branding to national identity discourses and sheds light on how semiotic analysis can be used in further explorations.

The last article, authored by Regina Lenart-Gansiniec (2018), reflects on the methodology of research on the relatively new concept of crowdsourcing. Considered as a promising concept, with a wide range of applications in the management of companies and organizations belonging to the public sector, crowdsourcing has been receiving growing scholarly attention in recent years. As an emerging field, it has been approached from various perspectives, hence the scholarship provides a manifold of its distinct conceptualizations. With the aim of mapping and assessing the evolving knowledge base, the author has undertaken a systematic literature review on the subject. A thorough, context-sensitive analysis has involved bibliometric techniques as well as a critical assessment of the theoretical and empirical content. The identified key, methodology-related challenges faced by scholars investigating crowdsourcing extend across a confused understanding of the nature of crowdsourcing, the multidimensionality and many-sidedness of the concept, the adopted epistemological stance and the methods used for measuring crowdsourcing. Interestingly, in order to provide a more fine-grained insight into the potential and limitations of quantitative and qualitative approaches, 
the author has decided to present an in-depth analysis of two well-received studies on crowdsourcing representing opposite epistemological stances. The contribution of the study relates not only to the systematization of the relevant intellectual territory but more importantly to the indication of sensitive and contentious areas that could be addressed in order to develop the existing body of knowledge on crowdsourcing further.

The articles included in this special issue do not total a comprehensive picture of the current state of qualitative research in management. Instead, they provide insightful snapshots reflecting methodological diversity and pluralism observed in qualitative management research. These selected papers present valuable examples of practices of using qualitative methods, where reflections generate a rich understanding of managerial processes whilst appreciating their subtleties in different contexts. Moreover, although this special collection contributes to the promotion of method diversity, it emphasizes the fundamental issue of addressing the primary questions which underlie qualitative research choices. We hope the discussions presented in the articles will inspire and stimulate new developments in qualitative management research.

\section{Acknowledgments}

As editors of this special issue, we would like to thank all the authors, who submitted their articles, for the work performed and the fruitful cooperation during the editorial process. On our own behalf, and on behalf of all the authors, we would like to express our gratitude to the reviewers for their helpful and insightful suggestions. Our special appreciation goes to Prof. Anna Ujwary-Gil, the editor-in-Chief of JEMI, for her inexhaustible patience and sustained, extremely professional support.

\section{References}

Bartunek, J. M., Rynes, S. L., \& Ireland, R.D. (2006). What makes management research interesting, and why does it matter? Academy of Management Journal, 55, 9-15.

Bazeley, P. (2015). Mixed methods in management research: Implications for the field. The Electronic Journal of Business Research Methods, 13(1), 27-35.

Bluhm, D. J., Harman, W., Lee, T. W., \& Mitchell, T. R. (2010). Qualitative research in management: A decade of progress. Journal of Management Studies, 48(8), 1866-1891.

Cassell, C. (2016). European qualitative research: A celebration of diversity and a cautionary tale. European Management Journal, 34(5), 453-456.

Cassell, C., \& Symon, G. (2015). Qualitative research in organizations and management: Ten years on. Qualitative Research in Organizations and Management: An International Journal, 10(4), 1-10. 
Corley, K. G., \& Gioia, D. A. (2011). Building theory about theory building: What constitutes a theoretical contribution? Academy of Management Review, 36(1), 12-32.

Czakon, W. (2009). Mity o badaniach jakościowych w naukach o zarządzaniu (Myths about qualitative research in management sciences). Przeglqd organizacji (Organization Review), 9, 13-17.

Cyfert S. (2014). Od redaktora naczelnego (From the editor). Organizacja $i$ Kierowanie (Organization and Management), 1(161), 7-9.

Daba-Buzoianu, C., Bira, M., Tudorie, C., \& Duduciuc, A. (Eds.). (2017). Exploring Communication Through Qualitative Research. Newcastle: Cambridge Scholars Publishing.

Daba-Buzoianu, C., \& Bira, M. (2017). A theoretical approach to qualitative research in communication. In C. Daba-Buzoianu, M. Bira, C. Tudorie, \& A. Duduciuc (Eds.), Exploring Communication Through Qualitative Research (pp. 9-19). Newcastle: Cambridge Scholars Publishing.

Denzin, N., \& Lincoln, Y. (Eds.). (1994). Handbook of Qualitative Research. London: Sage Publication Inc.

Edmondson, A. C., \& McManus, S. E. (2007). Methodological fit in management field research. Academy of Management Review, 32(4), 1155-1179.

Eisenhardt, K. M. (1989). Building theories from case study research. Academy of Management Review, 14(4), 532-550.

Eisenhardt, K. M., Graebner, M. E., \& Sonenshein, S. (2016). Grand challenges and inductive methods: Rigor without rigor mortis. From the editors. Academy of Management Journal, 59(4), 1113-1123.

Eisenhardt, K. M., \& Graebner, M. E. (2007). Theory building from cases: Opportunities and challenges. Academy of Management Journal, 50(1), 25-32.

Gephart, R. (2004). From the editors. Qualitative research and the Academy of Management Journal. Academy of Management Journal, 47(4), 454-462.

Gioia, D. A., Corley, K. G., \& Hamilton, A. L. (2013). Seeking qualitative rigor in inductive research: Notes on the Gioia methodology. Organizational Research Methods, 16(1), 15-131.

Golden-Biddle, K., \& Locke, K. (2007). Composing Qualitative Research. Thousand Oaks, CA: Sage Publications Inc.

Guba, E. G., \& Lincoln, Y. S. (1994). Competing paradigms in qualitative research. In N. K. Denzin \& Y. S. Lincoln (Eds.), Handbook of Qualitative Research (pp. 105-117). Thousand Oaks CA: Sage Publication Inc.

Lindlof, T. R., \& Taylor, B. C. (2011). Qualitative Communication Research Methods. Washington DC: Sage Publications Inc.

Jørgensen, L., Jordan, S., \& Mitterhofer, H. (2012). Sensemaking and discourse analyses in inter-organizational research: A review and suggested advances. Scandinavian Journal of Management, 28, 107-120.

Kociatkiewicz, J., \& Kostera, M. (2014). Zaangażowane badania jakościowe (Commited qualitative research in management studies). Problemy Zarzqdzania (Management Issues), 12(1), 9-17. 
Langley, A., Smallman, C., Tsoukas, H., \& Van de Ven, A. H. (2013). Process studies of change in organization and management: Unveiling temporality, activity, and flow. Academy of Management Journal, 56(1), 1-13.

Lee, T. W., Mitchell, T. R., \& Sablynski, C. J. (1999). Qualitative research in organizational and vocational psychology, 1979-1999. Journal of Vocational Behavior, 55, 161-187.

Maher, C., Hadfield, M., Hutchings, M., \& de Eyto, A. (2018). Ensuring rigor in qualitative data analysis. International Journal of Qualitative Methods, 17(1), 1-13.

Mason, J. (2017). Qualitative Researching. London: Sage Publications Inc.

Molina-Azorín, J. F. (2011). The use and added value of mixed methods in management research. Journal of Mixed Methods Research, 5(1), 7-24.

Molina-Azorín, J. F., \& Cameron, R. (2015). History and emergent practices of multimethod and mixed methods in business research. In S. Hesse-Biber \& R.B. Johnson (Eds.), Oxford Handbook of Multimethod and Mixed Methods Research Inquiry (pp. 466-485). New York: Oxford University Press.

Najda-Janoszka, M. (2016a). Dynamic Capability-Based Approach to Value Capture. Krakow: Jagiellonian University Press.

Najda-Janoszka, M (2016b). Responding to discontinuities - alternating action patterns of value appropriation. In. A. Zbuchaea, C. Bratianu, F. Pinzaru, \& R. D. Leon (Eds.) Strategica 2016: Opportunities and Risks in the Contemporary Business Environment (pp. 483-494). Bucharest: Tritonic.

Paille, P. (2002). Qualitative research [Cercetarea calitativă]. In A. Mucchielli (Ed.), Dictionary of Qualitative Methods in Humanities and Social Sciences [Dicționar al metodelor calitative în științele umane și sociale] (pp. 55-59). Iași: Polirom (Romanian version)

Pratt, M. G. (2009). For the lack of a boilerplate: Tips on writing up (and reviewing) qualitative research. Academy of Management Journal, 52(5), 856-62.

Seidel, V. P., \& O'Mahoney, S. (2014). Managing the repertoire: Stories, metaphors, prototypes, and concept coherence in product innovation. Organization Science, 25, 691-712.

Silverman, D. (2005). Doing Qualitative Research. A Practical Handbook. Los Angeles: Sage Publications Inc.

Sinkovics, R. R., \& Alfoldi, E. A. (2012). Progressive focusing and trustworthiness in qualitative research. Management International Review, 52, 817-845.

Symon, G., Cassell, C., \& Johnson, P. (2018). Evaluative practices in qualitative management research: A critical review. International Journal of Management Reviews, 20(1),134-154.

Vaara, E., Sonenshein, S., \& Boje, D. (2016). Narrative as sources of stability and change in organizations: Approaches and directions for future research. The Academy of Management Annals, 10, 495-560.

Van Maanen, J. (1998). Different strokes: Qualitative research in the Administrative Science Quarterly from 1956 to 1996. In J. Van Maanen (Ed.) Qualitative Studies of Organizations (pp. ix-xxxii). Thousand Oaks, CA: Sage Publications Inc. 
Willig, C. (2013). Introducing Qualitative Research in Psychology. New York: McGraw-Hill Education.

\section{Biographical notes}

Marta Najda-Janoszka is Dr. Hab., Associate Professor at Jagiellonian University in Krakow. In 2006 she was awarded a doctoral degree in management sciences at Krakow University of Economics. Her doctoral work developed a dynamic perspective of the virtualization process. In 2017 she completed a habilitation in strategic management (postdoc) with a book "Dynamic capability-based approach to value appropriation." Focusing mainly on inter-organizational collaboration she is the author and co-author of over 70 scientific works including journal articles, student text-books, and monographic books. Principal and co-investigator in over twenty research projects with results presented at international conferences. Her research and teaching activities are grounded in the strategic management field with particular emphasis on managing processes of value creation and value appropriation in varied inter-organizational constellations. She is a member of the Strategic Management Society.

Corina Daba-Buzoianu is a Ph.D., Associate Professor at the National University of Political Studies and Public Administration, Bucharest (SNSPA), where she teaches Crisis communication and Image analysis at BA and MA level and at the Health communication postgraduate program. In 2011 she was a guest Ph.D. researcher at the University of Amsterdam. She defended her Ph.D. in 2012 in Romania with a thesis on epistemology of image and was a postdoctoral researcher in qualitative research in communication between 2013-2014. Corina Daba-Buzoianu is the initiator of a distinctive research topic in SNSPA regarding qualitative research in communication. 
